\title{
Characteristics of virulence, resistance and genetic diversity of strains of Salmonella Infantis isolated from broiler chicken in Brazil ${ }^{1}$
}

\author{
Eliane P. Mendonça ${ }^{2 *}$ (D), Roberta T. Melo ${ }^{3}$ (D), Milene R.M. Oliveira ${ }^{3}$, \\ Guilherme P. Monteiro ${ }^{3}$, Phelipe A.B.M. Peres ${ }^{3}$, Belchiolina B. Fonseca ${ }^{3}$, \\ Audecir Giombelli ${ }^{4}$ and Daise A. Rossi ${ }^{3}$
}

\begin{abstract}
Mendonça E.P., Melo R.T., Oliveira M.R.M., Monteiro G.P., Peres P.A.B.M., Fonseca B.B., Giombelli A. \& Rossi D.A. 2020. Characteristics of virulence, resistance and genetic diversity of strains of Salmonella Infantis isolated from broiler chicken in Brazil. Pesquisa Veterinária Brasileira 40(1):29-38. Laboratório de Biologia Molecular, Faculdade de Medicina Veterinária, Universidade de Uberaba, Av. Nenê Sabino 1801, Bloco 2D, sala 52, Universitário, Uberaba, MG 38055-500, Brazil. E-mail: eliane_vet@yahoo.com.br

Salmonella Infantis is frequently associated with human infections worldwide and is transmitted by consumption of contaminated foods, particularly those of animal origin, especially the chicken meat. We aimed to evaluate virulence characteristics, antimicrobial resistance and the genetic similarity of 51 strains of $S$. Infantis isolated from samples of poultry origin. The strains were isolated from 2009 to 2010 in a company with full cycle of broiler's production in the state of São Paulo, Brazil. The antimicrobial susceptibility test was performed and, by PCR, we evaluated the presence of the genes IpfA (hem-adhesion), agfA (hem-biofilm) and sefA (hem-adhesion) and resistance genes to beta-lactams ( $b l a_{\mathrm{TEM}}, b l a_{\mathrm{SHV}}, b l a_{\mathrm{CTX}-\mathrm{M}}$ and $\left.b l a_{\mathrm{AmpC}}\right)$. The phylogenetic relationship was determined by RAPD-PCR method. Among the drugs tested, the highest percentages of resistance were to amoxicillin (35.3\%) and to sulfonamide (15.7\%). Eleven antimicrobial resistance patterns were identified (A1 to A11), none of them presented a multiresistance profile ( $>3$ antimicrobials classes). There was $100 \%$ of positivity for the agfA gene, $92.2 \%$ for the lpfA gene, and no strain presented the sefA gene. Most of the isolates showed similarities in virulence potential, since they were simultaneously positive for two studied genes, agfA and $\operatorname{lpfA}(92.2 \%, 47 / 51)$. Of the $18(35.3 \%)$ strains resistant to antimicrobials of the $\beta$-lactam class, $10(55.5 \%)$ were positive to bla $_{\text {AmpC }}$ gene, five $(27.8 \%)$ for $b l a_{\text {Стх-м }}$, two $(11.1 \%)$ to $b l a_{\mathrm{SHV}}$ and no strain presented the $b l a_{\mathrm{TEM}}$ gene. The phylogenetic evaluation has shown the presence of five clusters (A, B, C, D and E) with similarity greater than $80 \%$, and three distinct strains which were not grouped in any cluster. Cluster B grouped 33 strains, all positive for IpfA and agfA genes, from both, the broiler farming facility and the slaughterhouse, persistent throughout all the study period. This cluster also grouped 18 strains clones with genetic similarity greater than $99 \%$, all isolated in the slaughterhouse. The presence of virulence genes associated with persistent strains clones for a long period, warns to the possibility of $S$. Infantis to form biofilm, and should be constantly monitored in broilers' production chain, in order to know the profile of the strains that may contaminate the final product and evaluate the hazards that represents to public health.
\end{abstract}

INDEX TERMS: Virulence genes, resistance genes, genetic diversity, strains, Salmonella Infantis, broiler chicken, Brazil, RAPD-PCR, antimicrobial resistance, Salmonella, genes, chickens.

\footnotetext{
${ }^{1}$ Received on November 4, 2018.

Accepted for publication on April 1, 2019.

${ }^{2}$ Laboratório de Biologia Molecular, Faculdade de Medicina Veterinária, Universidade de Uberaba (UNIUBE), Av. Nenê Sabino, 1801, Bloco 2D, sala 52, Universitário, Uberaba, MG, 38055-500, Brazil. *Corresponding author: eliane_vet@yahoo.com.br
}

\footnotetext{
${ }^{3}$ Laboratório de Biotecnologia Animal Aplicada, Faculdade de Medicina Veterinária, Universidade Federal de Uberlândia (UFU), R. Ceará, s/n, Bloco 2D, Sala 43, Umuarama, Uberlândia, MG 38402-018, Brazil.

${ }^{4}$ Faculdade de Ciências Farmacêuticas da Universidade Federal de Minas Gerais (UFMG), Av. Presidente Antônio Carlos, 6627, Campus Pampulha, Belo Horizonte, MG 31270-901, Brazil.
} 
RESUMO.- [Características de virulência, resistência e diversidade genética de estirpes de Salmonella Infantis isoladas de frangos de corte no Brasil.] Salmonella Infantis é frequentemente associada a infecções humanas no mundo todo sendo transmitida pelo consumo de alimentos contaminados, principalmente aqueles de origem animal, com destaque para a carne de frango. Objetivou-se avaliar características de virulência, resistência antimicrobiana e a similaridade genética de 51 estirpes de $S$. Infantis isoladas em amostras de origem avícola. As estirpes foram isoladas no período de 2009 a 2010 em uma empresa com ciclo completo de produção de frango de corte, localizada no estado de São Paulo, Brasil. Foi realizado o teste de susceptibilidade antimicrobiana e pela técnica de PCR, foi avaliada a presença dos genes lpfA (fímbria-adesão), agfA (fímbria-biofilme) e sefA (fímbria-adesão) e os genes de resistência aos beta-lactâmicos $\left(b l a_{\text {TEM }}, b l a_{\mathrm{SHV}}\right.$. bla $a_{\text {стх-ме }} b l a_{\text {AmpC }}$. A relação filogenética foi determinada pelo método de RAPD-PCR. Dentre as drogas testadas, os maiores percentuais de resistência foram para amoxacilina com $35,3 \%$ e sulfonamida com $15,7 \%$. Onze perfis de resistência aos antimicrobianos foram identificados (A1 a A11), sendo que nenhum deles apresentou perfil de multirresistência ( $>3$ classes de antimicrobianos). Houve $100 \%$ de positividade para o gene agfA, 92,2\% para o gene IpfA e nenhuma estirpe apresentou o gene sefA. A maioria dos isolados apresentaram semelhanças no potencial de virulência, pois foram positivos simultaneamente para dois genes estudados, agfA e lpfA $(92,2 \%-47 / 51)$. Das $18(35,3 \%)$ estirpes resistentes aos antimicrobianos da classe dos $\beta$-lactâmicos, 10 (55,5\%) foram positivas para o gene $b l a_{\text {Amp }}$, cinco $(27,8 \%)$ para $b l a_{\text {СTX-M, }}$ duas $(11,1 \%)$ para bla $_{\mathrm{SHV}}$ e nenhuma estirpe apresentou o gene $b l a_{\text {ТЕМ }}$ A avaliação filogenética demonstrou a presença de cinco clusters (A, B, C, D e E) com similaridade superior a 80\%, e três estirpes distintas que não foram agrupadas em nenhum dos clusters. 0 cluster $\mathrm{B}$ agrupou 33 estirpes, todas positivas para

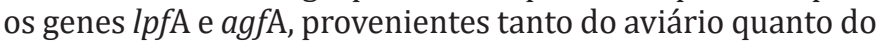
matadouro frigorífico, persistentes durante todo o período do estudo. Este cluster ainda agrupou 18 estirpes clones com similaridade genética superior a 99\%, todas isoladas no matadouro frigorífico. A presença dos genes de virulência, associada à persistência das estirpes clones durante um longo período do estudo, alertam para a possibilidade de $S$. Infantis em formar biofilme, devendo ser constantemente monitorada na cadeia de produção avícola, especialmente no ambiente de abate, de forma a conhecer o perfil das estirpes que podem contaminar o produto final e assim avaliar os perigos que representam para a saúde pública.

TERMOS DE INDEXAÇÃO: Virulência, genes de resistência, diversidade genética, estirpes, Salmonella Infantis, frangos de corte, Brasil, Salmonella, RAPD-PCR, resistência antimicrobiana.

\section{INTRODUCTION}

Salmonellosis is one of the most common food-borne diseases, considered a complex zoonosis that affects global public health. In Brazil, it is the primary cause of outbreaks in which the etiological agent is identified (Brasil 2008a). The intestinal tract of a wide variety of animals is the reservoir of this bacterium, which can still survive in diverse environments, explaining its high potential for dissemination. The broiler chicken is one of the main reservoirs of this pathogen, with a high frequency of contamination of the final product in the slaughterhouse (EFSA 2014, 2015). Thus, the consumption of chicken meat is considered a risk factor for human infection by Salmonella (FAO-WHO 2009). In order to reduce the prevalence of this agent and establish an adequate level of consumer protection, the Ministry of Agriculture recently implemented a controlling and monitoring program for Salmonella sp. both in commercial establishments of broiler chickens and turkeys, as in slaughter and breeding environments (Brasil 2016).

More than 2,600 serotypes of Salmonella are known, but a limited number are associated with most human diseases, and the prevalence of different serovars may change over time (EFSA 2014). Since the late 1970s, serovar Infantis has been increasingly registered in countries such as Argentina, Australia, Brazil, the Netherlands, Finland, Canada, Hungary, Japan, New Zealand and Russia (Miller et al. 2010). Along with $S$. Enteritidis and $S$. Typhimurium, $S$. Infantis has been reported for involvement in human cases of the disease, and is the most frequently isolated in the live bird as well as in the chicken meat (EFSA 2015). In Brazil, this serovar is also among those most isolated from broiler samples of producing farms (Medeiros et al. 2011, Voss-Rech et al. 2015).

The long-term use of antimicrobials in animal husbandry exerts selection pressure on bacteria population, thus favoring the survival of resistant strains of Salmonella, which can be transferred to humans through the consumption of contaminated food and can lead to antibiotic therapy failure (Lai et al. 2014). The dynamics of resistance transmission and the evolution of populations of resistant bacteria are difficult to elucidate and are associated with the genetic transfer of so-called resistance genes (Alekshun \& Levy 2007). Several international health authorities consider the occurrence of antimicrobial resistance in zoonotic micro-organisms as one of the major emerging problems of importance to public health (Moore et al. 2006).

The extended-spectrum $\beta$-lactamase (ESBL) is an enzyme that allows bacteria to become resistant to a wide variety of penicillins and cephalosporins, and the bacteria that contain this enzyme are resistant to the $\beta$-lactam penicillins, cephalosporins of 3rd and 4th generations and monobactams, remaining sensitive to carbapenems, cephamycins (2nd generation of cephalosporins) and $\beta$-lactamase inhibitors. In the United States an estimated 26,000 infections occur annually due to ESBL-producing bacteria, resulting in about 1,700 deaths, generating large hospital costs in the country (CDC 2014).

The molecular mechanisms involved in the pathogenicity of Salmonella spp. are also complex, and investigations on virulence factors have shown that pathogenic strains are differentiated from those that are not by the presence of pathogenicity specific genes, which are located in the Pathogenicity Islands (PI) (Kaur \& Jain 2012). Furthermore, it is known that there is a genetic differentiation in isolates of the same serotype, determining variations for virulence in different strains (Borges et al. 2013). These genes provide the microorganism with adhesion, invasion, colonization, survival and multiplication in the host cells, determining a series of events that trigger the disease (Suzuki 1994, Vieira 2009). There are many types of fimbriae that help Salmonella in the intestinal adhesion including long polar fimbriae (Lpf), aggregative fimbriae (Agf), whose operon is highly conserved among the isolates of this pathogen, and the 
$S$. Enteritidis (Sef) fimbria, identified in serotypes of group D (Bäumler et al. 1997).

The evaluation of the spread of pathogens along the food chain is of great importance for industries to act in the prevention and implementation of more effective control programs. Molecular typing methods for Salmonella have been widely used in order to establish the phylogenetic relationship between bacterial isolates and provide important data for the understanding of epidemiology. In this sense, Random Amplified Polymorphic DNA (RAPD-PCR) is a tool widely used for epidemiological studies in several countries because of its high discriminatory power (Turki et al. 2014, Vázquez-Garcidueñas et al. 2014).

The aim of this study was to evaluate the resistance characteristics of $\beta$-lactams by evaluating the presence of the bla $a_{T E M^{\prime}}$ bla ${ }_{S H V^{\prime}}, b l a_{C T X M}$ and $b l a_{A m P C}$ genes and also to investigate the virulence genes agfA, sefA and IpfA that are involved in the adhesion and the process of biofilm formation, in strains of $S$. infants isolated from samples of poultry origin, from the broiler breeding environment to the slaughterhouse. It was also evaluated their dissemination within the production chain, in order to estimate the danger they pose to human health.

\section{MATERIALS AND METHODS}

Origin of the strains. Salmonella Infantis strains were derived from a previous study that monitored Salmonella spp. in two units of the same company, with a complete cycle of broiler chicken production and integration system, located in the state of São Paulo (SP) and Mato Grosso do Sul (MS), during the period from 2009 to 2010. The slaughterhouse was inspected by the federal inspection service and the chicken meat produced was marketed throughout the national territory and exported. Samples were collected at all stages of the production cycle, from the poultry rearing environment to the ready-to-trade industrialized final product, including samples from the slaughter environment.

Considering the total of 239 strains, 187 were isolated in SP and 52 in MS. S. Infantis was not identified in the MS unit, but in SP, it was the most prevalent serovar, representing $27.27 \%$ (51/187) of the isolates.

Among the 51 strains of $S$. Infantis used in this study, 14 were isolated in the environment of broiler poultry (samples of disposable foot socks and sampling of drag swabs of the shed were taken when the chickens were with approximately 30 days). Thirty-seven samples were obtained from the slaughterhouse and collected at the points required by the Pathogen Reduction Program - PRP (Brasil 2003) and, in addition, other points with a higher frequency of isolation of Salmonella in the routine of the industries studied, including samples of meat cuts (1), mechanically separated meat (MSM) (10), scalding water (1) and water from the pre-cooling tanks (1).

The antigenic typing was carried out by the "Fundação Instituto Oswaldo Cruz" (Fiocruz) in the state of Rio de Janeiro.

Antimicrobial sensitivity test. The susceptibility of the strains to the antimicrobial agents was evaluated by the disc diffusion technique, using a protocol recommended by the Clinical and Laboratory Standards Institute (CLSI 2013). The antimicrobials choices were based on the use of these drugs in veterinary and human medicine and the occurrence of resistance in both areas. The antimicrobials and microgram concentrations tested were: amoxicillin $(10 \mu \mathrm{g})(\beta$-lactam/penicillin), norfloxacin $(10 \mu \mathrm{g})$ (fluorquinolone), neomycin $(30 \mu \mathrm{g})$ (aminoglycoside), gentamicin $(10 \mu \mathrm{g})$ (aminoglycoside), trimetropin $(5 \mu \mathrm{g})$ (pyrimidine), ceftazidime $(30 \mu \mathrm{g})(\beta$-lactam/cephalosporin), chloramphenicol $(30 \mu \mathrm{g})$ (phenicol), imipenem $(10 \mu \mathrm{g})(\beta$-lactam/carbapenem), tetracycline $(30 \mu \mathrm{g})$ (tetracycline), sulfonamide $(300 \mu \mathrm{g})$ (sulfonamide) (LABORCLIN ${ }^{\circledR}$ ). Inhibition zones were measured and the results were classified as sensitive, intermediate or resistant according to CLSI (2013) recommendations. Salmonella isolates that were resistant to three or more classes of antimicrobials were defined as multiresistant (Brasil 2008b). The strain Escherichia coli ATCC 25922 was used as a quality control of the sensitivity tests.

Research on virulence genes and antimicrobial resistance. Three virulence genes were investigated in $S$. infantis, related to the phases of adhesion and consequent lesion in intestinal cells (Table 1).

Extraction of the bacterial DNA was performed using the commercial DNA Purification Kit (Promega) according to the manufacturer's instructions. DNA quantification was done in a spectrophotometer (Femto $750^{\circledR}$ ) with a wavelength of $260 \mathrm{~nm}$.

For the polymerase chain reaction (PCR) analyzes of the virulence genes, the strain $S$. Enteritidis ATCC 13076 was used as the positive control. PCR reactions were performed from a final volume of $25 \mu \mathrm{L}$ containing $1 \mu \mathrm{L}$ of the DNA sample, $2.5 \mu \mathrm{l}$ of $10 \mathrm{X}$ buffer, $0.75 \mu \mathrm{l}$ of $50 \mathrm{mM} \mathrm{MgCl}, 1.25 \mu \mathrm{l}$ of $10 \mathrm{pmol} / \mu \mathrm{l}$ of the forward and reverse sequence of each primer (Invitrogen ${ }^{\circledR}$ ), $0.25 \mu$ l of $20 \mathrm{mM}$ of the mix of dNTPs (Invitrogen ${ }^{\circledR}$ ), $0.25 \mu \mathrm{L}$ of Taq $(5 \mathrm{U} / \mu \mathrm{L}$ )

Table 1. Virulence and resistance genes, primer sequences and amplicon sizes (bp)

\begin{tabular}{|c|c|c|c|}
\hline Gene & Primers & Molecular weight ${ }^{\mathrm{a}}$ & Reference \\
\hline sefA & $\begin{array}{l}\text { F:5'GATACTGCTGAACGTAGAAGG3' } \\
\text { R:5'GCGTAAATCAGGATCTGCAGTAGC3' }\end{array}$ & $488 \mathrm{bp}$ & Oliveira et al. (2003) \\
\hline$a g f \mathrm{~A}$ & $\begin{array}{l}\text { F:5'TCCACAATGGGGCGGCGGCG3' } \\
\text { R:5'CCTGACGCACCATTACGCTG3' }\end{array}$ & $350 \mathrm{bp}$ & Collinson et al. (1993) \\
\hline $\operatorname{lpfA}$ & $\begin{array}{l}\text { F:5'CTTTCGCTGCTGAATCTGGT3' } \\
\text { R:5'CAGTGTTAACAGAAACCAGT3' }\end{array}$ & $250 \mathrm{bp}$ & Bäumler \& Heffron (1995) \\
\hline$b l a_{\text {TЕM }}$ & $\begin{array}{l}\text { F: 5'CAGCGGTAAGATCCTTGAGA3' } \\
\text { R: 5'ACTCCCCGTCGTGTAGATAA3' }\end{array}$ & $643 \mathrm{bp}$ & Chen et al. (2004) \\
\hline$b l a_{\mathrm{SHV}}$ & $\begin{array}{l}\text { F: 5'GGCCGCGTAGGCATGATAGA3' } \\
\text { R: 5'CCCGGCGATTTGCTGATTTC3' }\end{array}$ & 714 bp & Chen et al. (2004) \\
\hline$b l a_{\text {стх-м }}$ & $\begin{array}{l}\text { F: 5'ATGTGCAGYACCAGTAARGTKATGGC3' } \\
\text { R: 5'TGGGTRAARTARGTSACCAGAAYCAGCGG3' }\end{array}$ & $593 \mathrm{bp}$ & Monstein et al. (2007) \\
\hline$b l a_{\mathrm{AmpC}}$ & $\begin{array}{l}\text { F: 5'CCCCGCTTATAGAGCAACAA3' } \\
\text { R: 5'TCAATGGTCGACTTCACACC3' }\end{array}$ & $634 \mathrm{bp}$ & Shahid (2010) \\
\hline
\end{tabular}


(Invitrogen ${ }^{\circledR}$ ) and $17.75 \mu \mathrm{L}$ of ultrapure $\mathrm{H}_{2} \mathrm{O}$. The samples were submitted to the following amplification cycles: initial denaturation at $94^{\circ} \mathrm{C}$ for 5 minutes, amplified in 35 denaturation cycles at $94^{\circ} \mathrm{C}$ for 45 seconds, annealing at $50^{\circ} \mathrm{C}$ for 30 seconds (sefA and lpfA), $66^{\circ} \mathrm{C}$ for 30 seconds $(a g f A)$, extension at $72^{\circ} \mathrm{C}$ for 90 seconds, final extension at $72^{\circ} \mathrm{C}$ for 10 minutes.

The strains that showed resistance to the antimicrobials of the $\beta$-lactam group were also evaluated for the presence of resistance genes described in Table 1. A Klebsiella pneumoniae field strain previously tested was used as the positive control for the presence of the four studied genes, provided by the "Laboratório de Microbiologia Molecular" of the "Universidade Federal de Uberlândia". The preparation of the mix for the PCR reactions was the same as for the virulence genes.

The amplification conditions followed the steps: initial denaturation at $94^{\circ} \mathrm{C}$ for 5 minutes, 30 denaturation cycles at $94^{\circ} \mathrm{C}$ for 45 seconds, annealing at $50^{\circ} \mathrm{C}$ for 45 seconds (blaTEM), $56^{\circ} \mathrm{C}$ for 45 seconds (blaSHV), $58^{\circ} \mathrm{C}$ for 1 minute (blaCTX-M) and $54^{\circ} \mathrm{C}$ for 1 minute (blaAmpC), extension at $72^{\circ} \mathrm{C}$ for 90 seconds, followed by a final extension of $72^{\circ} \mathrm{C}$ for 10 minutes.

Evaluation of genetic similarity between the strains. The isolates were submitted to gene analysis by RAPD-PCR using the protocol described by Oliveira et al. (2007). As a positive control, the $S$. Enteritidis strain ATCC 13076 was used.

RAPD-PCR reactions were performed with two primers, individually, which were described by Lin et al. (1996): 23L (5'-CCGAAGCTGC-3 ') and P1254 (5'-CCGCAGCCAA-3').

The RAPD-PCR technique was performed from a final volume of $25 \mu \mathrm{L}$ containing $1 \mu \mathrm{L}$ of DNA sample at $50 \mathrm{ng} / \mu \mathrm{L}, 2.5 \mu \mathrm{L}$ of $10 \mathrm{X}$ buffer, $0.75 \mu \mathrm{L}$ of $50 \mathrm{mM} \mathrm{MgCl}{ }_{2}, 0.25 \mu \mathrm{L}$ of $20 \mathrm{mM}$ dNTP mix (Invitrogen ${ }^{\circledR}$ ), $0.25 \mu \mathrm{L}$ of Taq $(5 \mathrm{U} / \mu \mathrm{L})$ (Invitrogen ${ }^{\circledR}$ ) and $17.75 \mu \mathrm{L}$ of ultrapure $\mathrm{H}_{2} \mathrm{O}$. The concentration of the primers was 50pmole for P1254 and 30 pmole for 23L (Invitrogen ${ }^{\circledR}$ ). The PCR reaction was conducted under the following conditions: one cycle of $94^{\circ} \mathrm{C}$ for 4 minutes, followed by 35 cycles of $94^{\circ} \mathrm{C}$ for 1 minute, $35^{\circ} \mathrm{C}$ for 1 minute, $72^{\circ} \mathrm{C}$ for 2 minutes, and final extension at $72^{\circ} \mathrm{C}$ for 5 minutes.

All PCR reactions were performed on the thermal cycler $\left(\right.$ Eppendorf $^{\circledR}$ ) and the amplified products separated in 1.5\% agarose gel electrophoresis for 120 minutes. The gel was stained with Syber Safe (Invitrogen ${ }^{\circledR}$ ) and visualized in UV translucent (Loccus Biotechnology ${ }^{\circledR}$ ).

Data analysis. The results were tabulated and submitted to analysis through descriptive statistics, calculating the percentages of antimicrobial resistance and the presence of virulence genes. For the analysis of genetic similarity between the strains, computational analysis was used by the GelCompar II Program (Comparative Analysis of Electrophoresis Patterns), version 1.5, Applied Maths Korthrijk, Belgium. The profiles obtained in the gel captured by the program were considered in the analysis and the similarity matrix was obtained by comparing pairs of strains using the Dice similarity coefficient, adopting 1\% of tolerance for each primer separately. The final analysis was based on the average of experiments. For the analysis of all the studied strains, the UPGMA (Unweighted Pair Group Method with Arighmetic Mean) method was used to construct the dendogram, in which the isolates were grouped in clusters when they presented homology equal or higher than $80 \%$ or in different genotypes when they had less than $80 \%$ of homology. The strains were compared considering the local of isolation, date of collection, profile of antimicrobial resistance and presence of virulence genes and resistance to $\beta$-lactams. Groups with homology greater than $99 \%$ were classified as clones.

\section{RESULTS AND DISCUSSION}

The occurrence of Salmonella Infantis only in the industrial unit of São Paulo, and not in the unit of Mato Grosso do Sul, is possibly due to the fact that the birds acquired by these units have different origins and come from different hatcheries.

Figure 1 presents the results of the resistance percentages for the antimicrobials tested in the 51 strains of $S$. Infantis, being these percentages the sum of the isolates classified as resistant and intermediate by the disc diffusion test. The highest resistance indexes were for amoxicillin (class of $\beta$-lactams/penicillin), with $35.3 \%$ (18/51), and for sulfonamide (sulfonamide class), with $15.7 \%$ (8/51). The lower percentages of resistance were found for tetracycline $(9.8 \%, 5 / 51)$ (tetracycline class) and ceftazidime $(5.9 \%, 3 / 51)$ ( $\beta$-lactam/cephalosporin of 3rd generation). All these antimicrobials belong to the exclusive veterinary classes in therapeutics, being prohibited their use as zootechnical additives of performance enhancers or as preservatives in animal feed, according to Normative Instruction no. 26 (Brasil 2009). All isolates were sensitive to norfloxacin, neomycin, gentamicin, trimethoprim, chloramphenicol and imipenem, thus suggesting an adequate use of these drugs in poultry production.

High levels of resistance to penicillin were also observed by Medeiros et al. (2011), in a study with Salmonella isolated from frozen carcasses in Brazil, where they found $44.8 \%$ of ampicillin-resistant strains. The high number of penicillin resistant strains, amoxicillin and ampicillin, warns of a major public health problem, since these drugs are considered the first choice for treatment of diseases in human medicine (WHO 2011). The serious public health problem is due to the possible transfer of resistant strains to man via contaminated food, especially those of poultry origin, which could lead to an ineffective therapy by the use of these drugs.

Lower percentage of resistance to sulfonamide, as found in this study, was identified by Rowlands et al. (2014) when evaluating strains of Salmonella spp. isolated from food in Brazil, where they found $2.1 \%$ of strains resistant to this drug. This result was not expected, since previous studies in Brazil reported a high frequency of resistance to this antimicrobial in Salmonella (Ghilardi et al. 2006, Bessa et al. 2007), suggesting the judicious use of this drug currently.

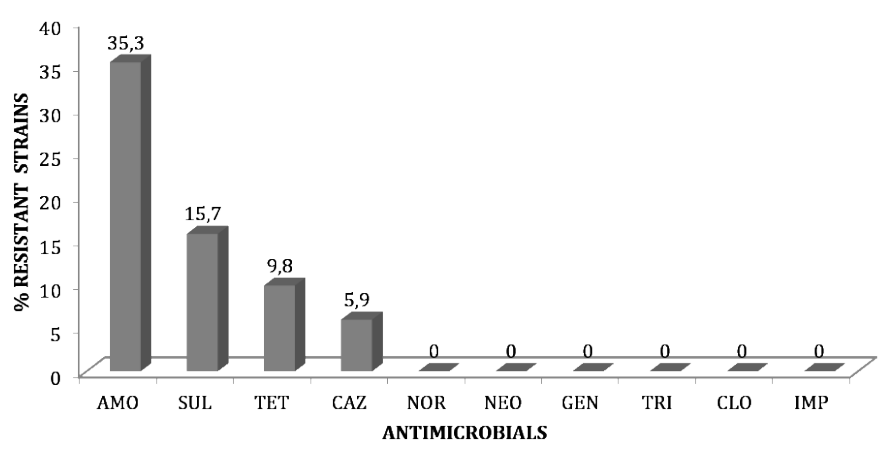

Fig.1. Frequency (\%) of antimicrobial resistance in Salmonella Infantis isolated in a poultry production chain located in the state of São Paulo, Brazil. AMO = amoxicillin $(10 \mu \mathrm{g})$, SUL = sulfonamide $(300 \mu \mathrm{g}), \mathrm{TET}=$ tetracycline $(30 \mu \mathrm{g}), \mathrm{CAZ}=$ ceftazidime $(30 \mu \mathrm{g})$, $\mathrm{NOR}=$ norfloxacin $(10 \mu \mathrm{g}), \mathrm{NEO}=$ neomycin $(30 \mu \mathrm{g}), \mathrm{GEN}=$ gentamicin $(10 \mu \mathrm{g}), \mathrm{TRI}=$ trimethoprim $(5 \mu \mathrm{g}), \mathrm{CLO}=$ chloramphenicol $(30 \mu \mathrm{g})$, IMP = imipenem $(10 \mu \mathrm{g})$. 
In Brazil, tetracycline have been banned as additives in animal feed since 1998, however, they are still used therapeutically and therefore may exert a selective pressure on microorganisms (Brasil 2009, Voss-Rech et al. 2015). Although levels of resistance to tetracycline, ceftazidime and sulfonamide are not considered alarming, it is critical to constantly evaluate the susceptibility of the isolates to these drugs, and thus to verify the resistance characteristics of Salmonella, to infer if the drugs administered in the birds are being properly used in animal production. Careful administration of antimicrobial agents and continuous surveillance are important initiatives that help define the best treatment and inhibit or hinder the selection and propagation of resistant strains between the flocks (Voss-Rech et al. 2015).

A study developed by Asgharpour et al. (2014), with strains of $S$. Infantis isolated from broiler chicken in Iran, found higher levels of resistance than those found in this study, with 70\% for amoxicillin, 66\% for trimethoprim-sulfamethoxazole, $100 \%$ for tetracycline, $28 \%$ for ceftazidime and $64 \%$ for chloramphenicol. According to Lai et al. (2014), the increase of resistance to sulfonamide and tetracycline is probably due to the use of these antimicrobials in animal feed, at subtherapeutic or therapeutic levels, to prevent diseases or to promote the animal growth.

The emergence of antimicrobial resistant bacteria to the classes of cephalosporins and fluoroquinolones is of great concern because both are used to treat serious human infections, and resistance to these drugs may cause serious complications in treatment (Hur et al. 2012, Kilonzo-Nthenge et al. 2013, Lai et al. 2014). Positive results were found in the present study, with only $5.9 \%$ of the strains showing resistance to ceftazidime, a third generation cephalosporin, whereas all Salmonella strains were sensitive to norfloxacin, a fluoroquinolone.

Eleven antimicrobial resistance profiles were identified (A1 to A11), being 27 (53\%) strains with resistance or intermediate resistance to one or two drugs, and there were no isolates with a multiresistant profile (Table 2). The most frequent profiles were A11 (47\%), with strains sensitive to

Table 2. Resistance profiles of 51 strains of Salmonella Infantis isolated in a poultry production chain located in the State of São Paulo, Brazil

\begin{tabular}{|c|c|c|c|}
\hline Profiles & $\begin{array}{l}\text { Antimicrobial } \\
\text { resistance }^{\mathrm{a}}\end{array}$ & $\begin{array}{c}\text { Number of } \\
\text { classes }^{\mathrm{b}}\end{array}$ & $\begin{array}{l}\text { Number of } \\
\text { strains (\%) }\end{array}$ \\
\hline $\mathrm{A} 1$ & AMO & 1 & $4(7.8)$ \\
\hline $\mathrm{A} 2$ & (AMO) & 1 & $10(19.6)$ \\
\hline $\mathrm{A} 3$ & SUL & 1 & $2(3.9)$ \\
\hline $\mathrm{A} 4$ & (SUL) & 1 & $2(3.9)$ \\
\hline A5 & TET & 1 & $1(2.0)$ \\
\hline A6 & (TET) & 1 & $1(2.0)$ \\
\hline A7 & AMO CAZ & 2 & $2(3.9)$ \\
\hline A8 & AMO (CAZ) & 2 & $1(2.0)$ \\
\hline A9 & (AMO) SUL & 2 & $1(2.0)$ \\
\hline $\mathrm{A} 10$ & TET SUL & 2 & 3 (5.9) \\
\hline A11 & Multi sensitive & - & $24(47.0)$ \\
\hline TOTAL & & & $51(100.0)$ \\
\hline
\end{tabular}

a Profiles in parentheses = strains with intermediate resistance to antimicrobials, ${ }^{b}$ Number of classes of antimicrobials to which the isolates showed resistance; $\mathrm{AMO}=$ amoxicillin, $\mathrm{CAZ}=$ ceftazidime, TET $=$ tetracycline, SUL $=$ sulfonamide. all antimicrobials tested, and A2 (19.6\%), showing strains with intermediate resistance for amoxicillin.

Voss-Rech et al. (2015), in a study with strains of Salmonella spp. isolated from broiler chicken in Brazil, also did not find multiresistance profiles for $S$. Infantis, which was the second most isolated serovar in the study, with $14.63 \%$. In another study performed in different Brazilian cities, $S$. Infantis was also the second most isolated serovar in chicken carcasses with $7.6 \%$. Of these, $57.8 \%$ were resistant to one or two antimicrobials, while $42.1 \%$ showed multiresistance profiles, with a higher resistance index for sulfonamide with 94.7\% (Medeiros et al. 2011). On the other hand, a study developed by Thai et al. (2012) in North Vietnam, found that $78.2 \%$ of the strains of S. infants isolated from both, chicken and pork meat, presented resistance from four to 13 antimicrobials, demonstrating the prevalence of the multiresistance characteristic for this serovar in this country.

The occurrence of multidrug resistant strains may be associated, in addition to inappropriate use of antimicrobials in industrial poultry, to the spread of antimicrobial resistance genes. The PREBAF, a monitoring program of prevalence and antimicrobial susceptibility profile of Salmonella spp. isolated from frozen chicken carcasses marketed in Brazil, emphasizes the importance of characterizing multiresistant clones as to their ability to host and disseminate antimicrobial resistance genes (Brasil 2008b).

Among the resistance genes encoding ESBL are bla ${ }_{A m p C^{\prime}}$ bla $_{C T X-M}$, bla $_{T E M}$ and bla ${ }_{S H V}$, which have been detected in Salmonella isolates from animal products in several countries (Rodriguez et al. 2009, Tamang et al. 2011). Of 18 (35.3\%) antimicrobial resistant strains of the $\beta$-lactam class (amoxicillin and ceftazidime), 11 (61.1\%) harbored one or more resistance genes, of which 10 (55.5\%) were positive for the bla ${ }_{A m p C}$ gene, five $(27.8 \%)$ for bla ${ }_{C T X-M}$, two $(11.1 \%)$ for $b l a_{S H V}$ and no strain showed the $b l a_{T E M}$ gene. Two strains showed the genes bla ${ }_{A m p C}$ and bla $_{C T X-M^{\prime}}$ and two other genes were positive for $b l a_{A m p C^{\prime}}$ bla $_{C T X-M}$ and bla $a_{S H V}$, concomitantly (Table 3).

All 10 strains harboring the bla ${ }_{A m p C}$ gene showed intermediate resistance or sensitivity to amoxicillin. The presence of the $A m p C$ gene in $S$. infantis isolated from chicken meat is a concern for Japanese public health agencies because this serovar is a major cause of human salmonellosis, and chicken meat is

Table 3. Relationship of resistance profiles and occurrence of resistance genes in 18 strains of Salmonella Infantis resistant to $\beta$-lactam antibiotics, isolated in a poultry production chain located in the State of São Paulo, Brazil

\begin{tabular}{ccc}
\hline Resistance profiles $^{\mathrm{a}}$ & Resistance genes & Number of strains (\%) \\
\hline AMO & bla $_{\mathrm{AmpC}}$ & $2(11.1)$ \\
AMO & bla $_{\text {AmpC }}$ bla $_{\mathrm{CTX-M}}$ bla $_{\mathrm{SHV}}$ & $2(11.1)$ \\
(AMO) & bla $_{\text {AmpC }}$ & $4(22.2)$ \\
(AMO) & bla $_{\text {Ampc }}$ bla & $2(11.1)$ \\
(AMX-M & $5(27.7)$ \\
AMO CAZ & - & $1(5.6)$ \\
AMO CAZ & bla $_{\text {CTX-M }}$ & $1(5.6)$ \\
AMO (CAZ) & - & $1(5.6)$ \\
TOTAL & - & $18(100.0)$ \\
\hline
\end{tabular}

a Profiles in parentheses $=$ strains with intermediate resistance to antimicrobials, $\mathrm{AMO}=$ amoxicillin, $\mathrm{CAZ}=$ ceftazidime. 
the main source of human infection in the country (Aviv et al. 2014, Noda et al. 2015).

Although phenotypically resistant to the antimicrobial agents of the $\beta$-lactam group, seven strains did not present any of the investigated genes (Table 3 ). This result indicates that resistance may be associated with the presence of other $\beta$-lactamases whose genes have not been evaluated in this study and/or other mechanisms of resistance to these antimicrobials, such as: efflux pumps, loss of porine expression, changes in penicillin-binding proteins (PBPs), presence of multiple or even new $\beta$-lactamases (Babic et al. 2006, Jacoby 2009).

The strains presented $100 \%$ of positivity for the agfA gene, $92.2 \%$ (47/51) for the IpfA and no strain showed the sefA gene.

The presence of the agfA in all studied strains suggests its ability to bind during the infection process, in addition to being associated with biofilm formation (Yoo et al. 2013). The detection of this gene in isolates of chicken meat cuts, carcasses, chiller and scalding water warns the danger of their presence during processing due to their possible capacity to produce biofilm, which can lead to contamination of the final product in poultry slaughterhouses.

The absence of sefA gene is consistent with the literature. The SefA fimbria encoded by this gene is described as being restricted to group D of Salmonella, which includes Enteritidis, Dublin, Moscow and Blegdon serotypes (Amini et al., 2010). However, knowing the possibility of horizontal transfer of fimbrial genes in serovars of the Salmonella genus, which allows their adaptation to different colonization situations (Rotger \& Casadesús 1999), it was proposed to evaluate the presence of this gene in $S$. infantilis. According to Bäumler et al. (1997), the acquisition of different fimbrial operons may have been one of the mechanisms by which Salmonella serovars succeeded in expanding their host range.

Most isolates of $S$. Infantis (92.2\% - 47/51) showed similarities in virulence potential, since they were positive simultaneously for two genes studied agfA and $\operatorname{lp} f A$. This indicates that these strains may be efficient in the adhesion process and in the formation of biofilms, which is associated with the presence of both genes. The presence of fimbriae, mediated by these genes, is extremely important in the infection process. It is possible that there are additive effects of adhesives Lpf and Agf on colonization of the intestine and expression of virulence in the host, indicating potential risk after infection. These findings were similar to other data obtained in previous studies that studied different serotypes of Salmonella (Borsoi et al. 2009, Cesco 2010, Borges et al. 2013).

The characteristics of resistance and virulence in $S$. Infantis shows that this serovar can be considered as potentially pathogenic and that genes related to these characteristics should be constantly monitored to understand and follow the process of adaptation of these strains throughout the productive process of the broiler and, consequently, in the human host. These strains can acquire and lose virulence genes over time, thus determining the spread of different genetic profiles (Moussa et al. 2013, Suez et al. 2013).

The genetic similarity analysis of $S$. Infantis showed a high proximity between the strains (Fig. 2), indicating that there are probably common sources of contamination.

Five clusters and three isolates with distinct profiles were identified, which could not be grouped with the other strains due to the genetic proximity being less than $80 \%$.
Cluster A grouped seven strains with homology of $80.4 \%$, all from the aviary, from environmental swab samples. This profile was present for a period of five months in the aviary environment. The common identification of the $\operatorname{lp} f A$ and $a g f A$ genes suggests the potential of these strains to fix themselves on surfaces and to produce biofilms in the environment of the aviary, allowing their maintenance in the place for long periods. The identification of the three resistance genes studied (SHV, CTX-M and AmpC) indicates the risk of the horizontal spread of resistance genes among the strains that can thus present multiresistant profiles. Therefore, it is necessary to establish more efficient and rigorous hygiene and biosafety measures to guarantee the control of this agent in the aviary's environment. According to Moura et al. (2014) the neglecting of biosecurity standards within the industry is a decisive factor for the maintenance of the microorganism in the environment.

The cluster with the highest number of isolates was $B$, composed of 33 strains with homology of $83.7 \%$ and therefore considered the main problem of this industry. This profile was isolated from the environmental swab of the aviary and the meat matrixes in the slaughterhouse. This genotype was identified over the two years of samples collection (2009 and 2010). The long period of permanence suggests that there was infection in successive animal flocks, associated to the maintenance of the microorganism in the aviary environment, and consequent contamination of the product in the slaughterhouse, which indicates that the cross contamination seems to be important in the dissemination of this genotype along the production chain. The presence of this profile in samples of swabs and disposable foot socks of the aviary, besides the scald and chiller water, suggests the negligence to the biosafety norms in the production unit that contributed to the contamination of the samples of carcasses and chicken meat cuts

Some authors state that there is influence of the environment on the contamination of the final product (Von Ruckert et al. 2009, Colla et al. 2012). Chiller and scald water are considered important factors in the dissemination of Salmonella in the slaughterhouse, since a large number of carcasses pass in the same water tank, increasing the chances of cross contamination (Mead et al. 2000).

The IpfA and agfA genes were also common in group B, suggesting the ability of the strains to produce biofilms, making it difficult to eliminate them within the industry.

Six clonal subgroups ( $>99 \%$ similarity) were identified in Cluster B (B1 to B6) composed of 18 strains. The B1 subgroup has isolates of chicken thigh, cartilage and disposable foot socks of the aviary. In B2 the strains are all of breast clipping. The B3 subgroup was detected in carcasses and neck. B4 contains isolated strains of chiller and scald water and cartilage. In B5, strains from thigh and chicken breast were grouped. Finally, B6 is composed of strains isolated from mechanically separated meat (MSM). According to Chu et al. (2009) the detection of clones in different samples demonstrates the propagation of Salmonella in the productive chain and the risk of transmission to humans.

The profile $C$ showed similarity of $94.1 \%$ composed of four strains, all of these samples from chicken's breast and skin in the slaughterhouse. Three of these strains were isolated in the same period (August of 2009), indicating that their 
23L P1254

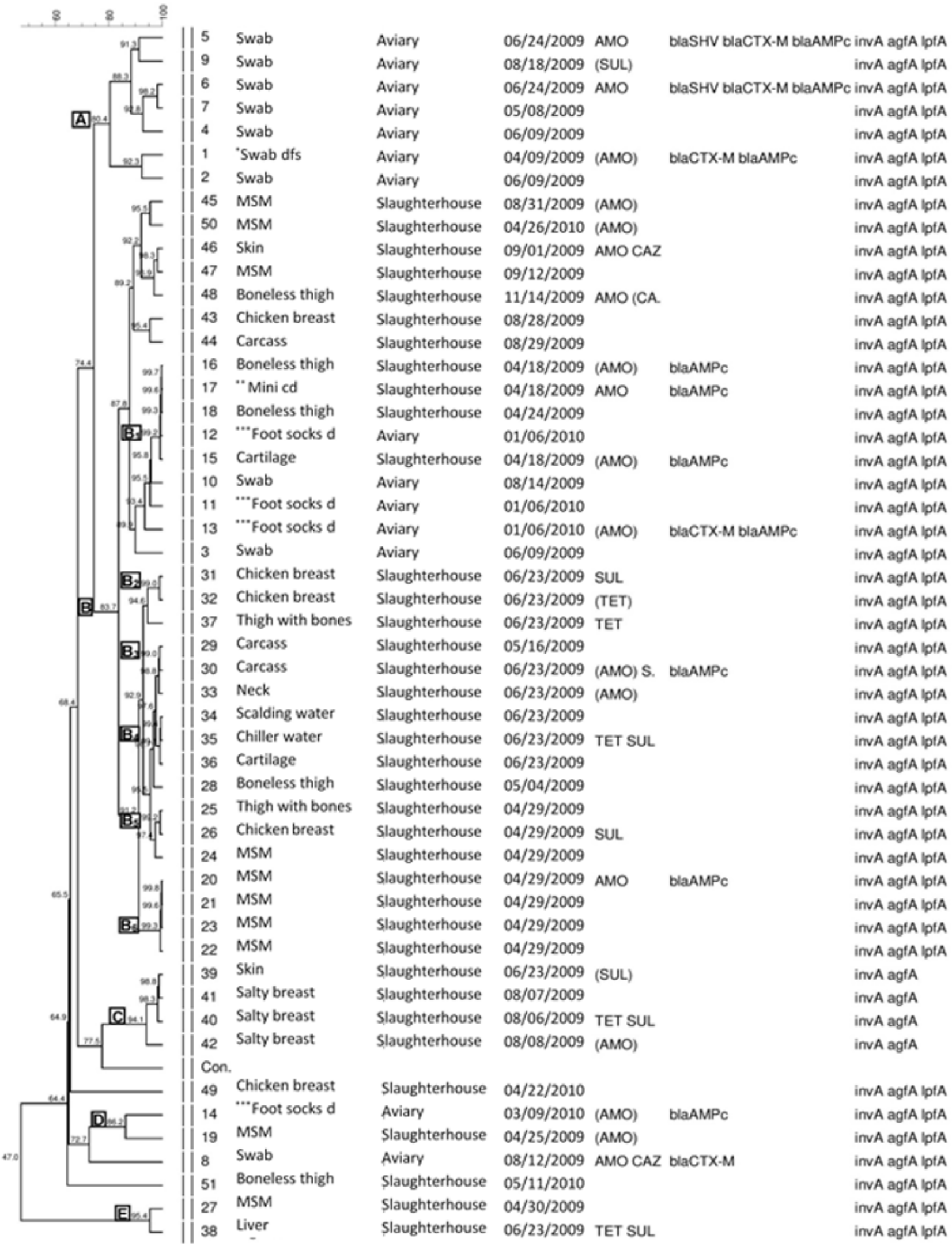

Fig.2. Comparative dendrogram of Salmonella Infantis using dice similarity coefficient with $1 \%$ of tolerance and UPGMA method with $0.80 \%$ of optimization. Profiles A to E = different clusters, with homology higher than 80\%; profiles B1 to B6 = clonal groups, with homology greater than $99 \%{ }^{*}$ Swab with disposable foot socks, ${ }^{* *}$ mini chicken drumsticks, ${ }^{* * *}$ disposable foot socks. 
permanence was temporary and that there is a possibility of greater ease in their control. In addition, the presence of the agfA gene alone in this profile may justify the shorter residence time, different from that found in other clusters. This fact does not eliminate the potential of biofilm formation of the strains; however, the absence of the IpfA gene may be the determining factor for its lesser ability to persist in the environment. The IpfA gene is involved in the process of adhesion to surfaces and epithelial cells that characterize an essential stage and prior to the biofilm formation process (Gibson et al. 2007).

Due to the fact that only two strains formed Clusters D and E, a more in-depth analysis of the data found was not possible.

\section{CONCLUSIONS}

The high percentage of resistance to amoxicillin warns of a risky condition, since this is a drug commonly used in human and veterinary medicine.

The high positivity for virulence genes, associated with the presence of $\beta$-lactam resistance genes in some isolates, suggests the pathogenic potential of Salmonella Infantis, the possibility of causing clinical disease in humans and the complications that can lead to the treatment of severe cases of salmonellosis.

Phylogenetic evaluation showed that strains from the aviary were fairly close to those isolated from the slaughterhouse, and persisted throughout the study period.

The presence of the IpfA and agfA genes associated with the persistence of strains in the environment warns of the potential of $S$. Infantis to form biofilms and should be constantly monitored in the poultry production chain and rigorous cleaning and decontamination measures applied in breeding environments, especially in the slaughterhouse, in order to minimize the contamination of the final product and the hazards to public health.

Acknowledgments.- To "Fundação de Amparo à Pesquisa do Estado de Minas Gerais" (FAPEMIG) and also the "Conselho Nacional de Desenvolvimento Científico e Tecnológico” (CNPq), for the financial support.

Conflict of interest statement.- The authors have no competing interests.

\section{REFERENCES}

Alekshun M.N. \& Levy S.B. 2007. Molecular mechanisms of antibacterial multidrug resistance. Cell 128(6):1037-1050.<http://dx.doi.org/10.1016/j. cell.2007.03.004 > <PMid:17382878>

Amini K., Salehi T.Z., Nikbahkht G., Ranjbar R., Amini J. \& Ashrafganjooei S.B. 2010. Molecular detection of invA and spv virulence genes in Salmonella Enteritidis isolated from human and animals in Iran. Afr. J. Microbiol. Res. $4(21): 2202-2210$.

Asgharpour F., Rajabnia R., Ferdosi Shahandashti E., Marashi M.A., Khalilian M. \& Moulana Z. 2014. Investigation of class i integron in Salmonella Infantis and its association with drug resistance. Jundishapur J. Microbiol. 7(5):e10019. <http://dx.doi.org/10.5812/jjm.10019><PMid:25147710>

Aviv G., Tsyba K., Steck N., Salmon-Divon M., Cornelius A., Rahav G., Grassl G.A. \& Gal-Mor 0. 2014. A unique megaplasmid contributes to stress tolerance and pathogenicity of an emergent Salmonella enterica serovar Infantis strain. Environ. Microbiol. 16(4):977-994. <http://dx.doi.org/10.1111/14622920.12351><PMid:24320043>
Babic M., Hujer A.M. \& Bonomo R.A. 2006. What's new in antibiotic resistance? Focus on $\beta$-lactamases. Drug Resist. Updat. 9(3):142-156. <http://dx.doi. org/10.1016/j.drup.2006.05.005><PMid:16899402>

Bäumler A.J. \& Heffron F. 1995. Identification and sequence analysis of IpfABCDE, a putative fimbrial operon of Salmonella Typhimurium. J. Bacteriol.177(8):2087-2097.<http://dx.doi.org/10.1128/jb.177.8.20872097.1995><PMid:7721701>

Bäumler A.J., Gilde A.J., Tsolis R.M., Van Der Velden A.W., Ahmer B.M. \& Heffron F. 1997. Contribution of horizontal gene transfer and deletion events to development of distinctive patterns of fimbrial operons during evolution of Salmonella serotypes. J. Bacteriol. 179(2):317-322. <http://dx.doi. org/10.1128/jb.179.2.317-322.1997> <PMid:8990281>

Bessa M.C., Michael G.B., Canu N., Canal C.W., Cardoso M., Rabsch W. \& Rubino S. 2007. Phenotypic and genetic characterization of Salmonella enterica subsp. enterica serovar Typhimurium. Res. Vet. Sci. 83(3):302-310.<http:// dx.doi.org/10.1016/j.rvsc.2007.01.006> <PMid:17336354>

Borges K.A., Furian T.Q., Borsoi A., Moraes H.L.S., Salle C.T.P. \& Nascimento V.P. 2013. Detection of virulence-associated genes in Salmonella Enteritidis isolates from chicken in south of Brazil. Pesq. Vet. Bras. 33(12):1416-1422. <http://dx.doi.org/10.1590/S0100-736X2013001200004>

Borsoi A., Santin E., Santos L.R., Salle C.T.P., Moraes H.L.S. \& Nascimento V.P. 2009. Inoculation of newly hatched broiler chicks with two Brazilian isolates of Salmonella Heidelberg strains with different virulence gene profile, antimicrobial resistance and pulsed field gel electrophoresis pattern to intestinal changes evaluation. Poult. Sci. 88(4):750-758. <http://dx.doi. org/10.3382/ps.2008-00466><PMid:19276418>

Brasil 2003. Institui o Programa de Redução de Patógenos - monitoramento microbiológico e controle de Salmonella sp. em carcaças de frangos e perus. Instrução Normativa no 70, de 06 de outubro de 2003, Diário Oficial da União, Seção 1, Ministério da Agricultura, Pecuária e Abastecimento (MAPA), Brasília, DF, p.9.

Brasil 2008a. Manual Integrado de Vigilância e Controle da Febre Tifoide. Departamento de Vigilância Epidemiológica, Secretaria de Vigilância em Saúde, Ministério da Saúde, Brasília, DF. 92p. Available at <http://bvsms. saude.gov.br/bvs/publicacoes/manual_vigilancia_controle_febre_tifoidel. pdf> Accessed on Jun. 24, 2015.

Brasil 2008b. Relatório do monitoramento da prevalência e do perfil de suscetibilidade aos antimicrobianos em Enterococos e Salmonelas isolados de carcaças de frango congeladas comercializadas no Brasil. Programa Nacional de Monitoramento da Prevalência e da Resistência Bacteriana em Frango (PREBAF), Agência Nacional de Vigilância Sanitária (Anvisa), Ministério da Saúde, Brasília, p.186.

Brasil 2009. Regulamento técnico para a fabricação, o controle de qualidade, a comercialização e o emprego de produtos antimicrobianos de uso veterinário. Instrução Normativa nํ26, de 09 de julho de 2009, Diário Oficial da União, Seção 1, Ministério da Agricultura, Pecuária e Abastecimento (MAPA), Brasília, DF, p.14.

Brasil 2016. Estabelece o controle e o monitoramento de Salmonella spp. nos estabelecimentos avícolas comerciais de frangos e perus de corte e nos estabelecimentos de abate de frangos, galinhas, perus de corte e reprodução, registrados no Serviço de Inspeção Federal (SIF), com objetivo de reduzir a prevalência desse agente e estabelecer um nível adequado de proteção ao consumidor. Instrução Normativa no 20, de 21 de outubro de 2016, Diário Oficial da União Seção 1, Ministério da Agricultura, Pecuária e Abastecimento (MAPA), Brasília, DF, p.13-16.

CDC 2014. Antibiotic resistance threats in the United States, 2013. Centers for Disease Control and Prevention, Atlanta, p.22-74. Available at <http:// www.cdc.gov/drugresistance/pdf/ar-threats-2013-508.pdf> Accessed on Aug. 19, 2015.

Cesco M.A.O. 2010. Pesquisa de Fatores Associados à Virulência de Salmonella Hadar através da reação em cadeia da polimerase (PCR). Master's Thesis in Veterinary Science, Faculdade de Veterinária, Universidade Federal do Rio Grande do Sul, Porto Alegre. 84p. 
Chen S., Zhao S., White D.G., Schroeder C.M., Lu R., Yang H., McDermott P.F., Ayers S. \& Meng J. 2004. Characterization of multiple-antimicrobialresistant Salmonella serovars isolated from retail meats. Appl. Environ. Microbiol. 70(1):1-7. <http://dx.doi.org/10.1128/AEM.70.1.1-7.2004> $<$ PMid:14711619>

Chu C., Wong D.W., Wang M.H., Lin H.H., Chen Y.S., Tien N., Shih M.C., Chen T.H. \& Chiu C.H. 2009. Genotyping, plasmid analysis, and antimicrobial susceptibility of Salmonella enterica serotype Enteritidis isolates from humans and chickens in central Taiwan. J. Formos. Med. Assoc. 108(10):765-771. <http://dx.doi.org/10.1016/S0929-6646(09)60403-4><PMid:19864196>

CLSI 2013. Performance standards for antimicrobial susceptibility testing: twenty-third informational supplement. CLSI M100-S23, Clinical and Laboratory Standards Institute, Wayne, p.44-49.

Colla F.L., Rodrigues L.B., Borsoi A., Dickel E.L., Nascimento V.P. \& Santos L.R. 2012. Isolamento de Salmonella Heidelberg em diferentes pontos da tecnologia de abate de frangos de corte. Arqs Inst. Biológico, São Paulo, 79(4):603-606.

Collinson K., Doig P.C., Doran J.L., Clouthier S., Trust T.J. \& Kay W.W. 1993. Thin aggregative fimbriae mediate binding of Salmonella Enteritidis to fibronectin. J. Bacteriol. 175(1):12-18. <http://dx.doi.org/10.1128/ jb.175.1.12-18.1993><PMid:8093237>

EFSA 2014. Scientific report of EFSA and ECDC: The European Union summary report on trends and sources of zoonoses, zoonotic agents and food-borne outbreaks in 2012. EFSA J. 12(2):3547.

EFSA 2015. The European Union summary report on trends and sources of zoonoses, zoonotic agents and food-borne outbreaks in 2013. EFSA J. 13(1):3991. <http://dx.doi.org/10.2903/j.efsa.2015.3991>

FAO-WHO 2009. Salmonella and Campylobacter in chicken meat: meeting report. Microbiological Risk Assessment Series no. 19, Food and Agriculture Organization of the United Nations/World Health Organization, Rome, p.3-32.

Gibson D.L., White A.P., Rajotte C.M. \& Kay W.W. 2007. AgfC and AgfE facilitate extracellular thin aggregative fimbriae synthesis in Salmonella Enteritidis. Microbiology 153(4):1131-1140.<http://dx.doi.org/10.1099/ mic.0.2006/000935-0><PMid:17379722>

Ghilardi A.C., Tavechio A.T. \& Fernandes S.A. 2006. Antimicrobial susceptibility, phage types, and pulsetypes of Salmonella Typhimurium, in São Paulo, Brazil. Mem. Inst. Oswaldo Cruz 101(3):281-286. <http://dx.doi.org/10.1590/ S0074-02762006000300010 > <PMid:16862323>

Hur J., Jawale C. \& Lee J.H. 2012. Antimicrobial resistance of Salmonella isolated from food animals: a review. Food Res. Int. 45(2):819-830. <http:// dx.doi.org/10.1016/j.foodres.2011.05.014>

Jacoby G.A. 2009. AmpC $\beta$-Lactamases. Clin. Microbiol. Rev. 22(1):161-182. <http://dx.doi.org/10.1128/CMR.00036-08><PMid:19136439>

Kaur J. \& Jain S.K. 2012. Role of antigens and virulence factors of Salmonella enterica serovar Typhi in its pathogenesis. Microbiol. Res. 167(4):199-210. <http://dx.doi.org/10.1016/j.micres.2011.08.001><PMid:21945101>

Kilonzo-Nthenge A., Rotich E. \& Nahashon S.N. 2013. Evaluation of drug-resistant Enterobacteriaceae in retail poultry and beef. Poult. Sci. 92(4):1098-1107. <http://dx.doi.org/10.3382/ps.2012-02581><PMid:23472034>

Lai J., Wu C., Wu C., Qi J., Wang Y., Wang H., Liu Y. \& Shen J. 2014. Serotype distribution and antibiotic resistance of Salmonella in food-producing animals in Shandong province of China, 2009 and 2012. Int. J. Food Microbiol. 180:30-38. <http://dx.doi.org/10.1016/j.ijfoodmicro.2014.03.030> $<$ PMid:24786550>

Lin A.W., Usera M.A., Barrett T.J. \& Goldsby R.A. 1996. Application of random amplified polymorphic DNA analysis to differentiate strains of Salmonella Enteritidis. J. Clin. Microbiol. 34(4):870-876. <PMid:8815099>

Mead G.C., Allen V.M., Burton C.H. \& Corry J.E. 2000. Microbial crosscontamination during air chilling of poultry. Brit. Poult. Sci. 41(2):158-162. <http://dx.doi.org/10.1080/713654915><PMid:10890210>

Medeiros M.A.N., Oliveira D.C.N., Rodrigues D.P. \& Freitas D.R.C. 2011. Prevalence and antimicrobial resistance of Salmonella in chicken carcasses at retail in 15 Brazilian cities. Revta Panam. Salud Publ. 30(6):555-560. <http:// dx.doi.org/10.1590/S1020-49892011001200010><PMid:22358402>

Miller T., Prager R., Rabsch W., Fehlhaber K. \& Voss M. 2010. Epidemiological relationship between Salmonella Infantis isolates of human and broiler origin. Lohmann Inform. 45(2):27-31.

Monstein H.J., Ostholm-Balkhed A., Nilsson M.V., Nilsson M., Dornbusch K. \& Nilsson L.E. 2007. Multiplex PCR amplification assay for rapid detection of blaSHV, blaTEM and blaCTX-M genes in Enterobacteriaceae. APMIS 115(12):1400-1408.<http://dx.doi.org/10.1111/j.1600-0463.2007.00722. x><PMid:18184411>

Moore J.E., Barton M.D., Blair I.S., Corcoran D., Dooley J.S.G., Fanning S., Kempf I., Lastovica A.J., Lowery C.J., Matsuda M., Mcdowell D.A., Mcmahon A., Millar B.C., Rao J.R., Rooney P.J., Seal B.S., Snelling W.J. \& Tolba 0. 2006. The epidemiology of antibiotic resistance in Campylobacter. Microbes Infect. 8(7):1955-1966. <http://dx.doi.org/10.1016/j.micinf.2005.12.030> $<$ PMid:16716632>

Moura M.S., Oliveira R.P., Melo R.T., Mendonça E.P., Fonseca B.B. \& Rossi D.A. 2014. Genes de virulência e diversidade genética em Salmonella spp. isoladas de amostras de origem suína. Arq. Bras. Med. Vet. Zootec. 66(5):1367-1375. <http://dx.doi.org/10.1590/1678-6809>

Moussa I.M., Aleslamboly Y.S., Al-Arfaj A.A., Hessain A.M., Gouda A.S. \& Kamal R.M. 2013. Molecular characterization of Salmonella virulence genes isolated from different sources relevant to human health. J. Food Agric. Environ. 11(2):197-201.

Noda T., Murakami K., Etoh Y., Okamoto F., Yatsuyanagi J., Sera N., Furuta M., Onozuka D., Oda T., Asai T. \& Fujimoto S. 2015. Increase in resistance to extended-spectrum cephalosporins in Salmonella isolated from retail chicken products in Japan. PLoS One 10(2):e0116927. <http://dx.doi. org/10.1371/journal.pone.0116927><PMid:25642944>

Oliveira F.A., Frazzon A.P.G., Brandelli A. \& Tondo E.C. 2007. Use of PCRribotyping, RAPD, and antimicrobial resistance for typing of Salmonella Enteritidis involved in foodborne outbreaks in southern Brazil. J. Infect. Develop. Ctries 1:170-176.

Oliveira S.D., Rodenbusch C.R., Michael G.B., Cardoso M.I.R., Canal C.W. \& Brandelli A. 2003. Detection of virulence genes in Salmonella Enteritidis isolates from different sources. Braz. J. Microbiol. 34(1):123-124. <http:// dx.doi.org/10.1590/S1517-83822003000500042>

Rodríguez I., Barownick W., Helmuth R., Mendoza M.C., Rodicio M.R Schroeter A. \& Guerra B. 2009. Extended-spectrum $\beta$ - lactamases and AmpC $\beta$-lactamases in ceftiofur-resistant Salmonella enterica isolates from food and livestock obtained in Germany during 2003-07. J. Antimicrob. Chemother. 64(2):301-309. <http://dx.doi.org/10.1093/jac/dkp195> $<$ PMid:19474065>

Rotger R. \& Casadesús J. 1999. The virulence plasmids of Salmonella. Int Microbiol. 2(3):177-184. <PMid:10943411>

Rowlands R.E.G., Ristori C.A., Ikuno A.A., Barbosa M.L., Jakabi M. \& Franco B.D.G.M. 2014. Prevalence of drug resistance and virulence features in Salmonella spp. isolated from foods associated or not with salmonellosis in Brazil. Revta Inst. Med. Trop. 56(6):461-467.

Shahid M. 2010. Citrobacter spp. simultaneously harboring blaCTX-M blaTEM, blaSHV, blaampC, and insertion sequences IS26 and orf513: na evolutionary phenomenon of recent concern for antibiotic resistance. J. Clin. Microbiol. 48(5):1833-1838. <http://dx.doi.org/10.1128/JCM.0146709><PMid:20220171>

Suez J., Porwollik S., Dagan A., Marzel A., Schorr Y.I., Desai P.T., Agmon V., McClelland M., Rahav G. \& Gal-Mor 0. 2013. Virulence gene profiling and pathogenicity characterization of non-typhoidal Salmonella accounted for invasive disease in humans. PLoS One 8(3):e58449. <http://dx.doi org/10.1371/journal.pone.0058449><PMid:23505508>

Suzuki S. 1994. Patogenicity of Salmonella Enteritidis in poultry. Int. J. Food Microbiol. 21(1/2):89-105. <http://dx.doi.org/10.1016/01681605(94)90203-8> <PMid:8155481>

Tamang M.D., Nam H.M., Kim T.S., Jang G.C., Jung S.C. \& Lim S.K. 2011. Emergence of extended-spectrum $\beta$ - lactamase (CTX-M-15 and CTX-M-14)-producing 
nontyphoid Salmonella with reduced susceptibility to ciprofloxacin among food animals and humans in Korea. J. Clin. Microbiol. 49(7):2671-2675. <http://dx.doi.org/10.1128/JCM.00754-11><PMid:21613434>

Thai T.H., Hirai T., Lan N.T. \& Yamaguchi R. 2012. Antibiotic resistance profiles of Salmonella serovars isolated from retail pork and chicken meat in North Vietnam. Int. J. Food Microbiol. 156(2):147-151. <http://dx.doi. org/10.1016/j.ijfoodmicro.2012.03.016><PMid:22497836>

Turki Y., Mehri I., Fhoula I., Hassen A. \& Ouzari H. 2014. Comparison of five molecular subtyping methods for differentiation of Salmonella Kentucky isolates in Tunisia. World J. Microbiol. Biotechnol. 30(1):87-98. <http:// dx.doi.org/10.1007/s11274-013-1414-1><PMid:23839713>

Vázquez-Garcidueñas M.S., Romero-Pérez N.L., Figueroa-Aguilar G.A., Jaime-Sánchez J.L. \& Vázquez-Marrufo G. 2014. Investigation of a foodborne Salmonella Oranienburg outbreak in a Mexican prison. J. Infect. Develop. Ctries 8(2):143-153. <http://dx.doi.org/10.3855/jidc.3367> $<$ PMid:24518623>
Vieira M.A. 2009. Ilhas de patogenicidade. Mundo Saúde 33(4):406-414.

Von Rückert D.A.S., Pinto P.S.A., Santos B.M., Moreira M.A.S. \& Rodrigues A.C.A. 2009. Pontos críticos de controle de Salmonella spp. no abate de frangos. Arq. Bras. Med. Vet. Zootec. 61(2):326-330. <http://dx.doi.org/10.1590/ S0102-09352009000200007>

Voss-Rech D., Vaz C.S.L., Alves L., Coldebella A., Leão J.A., Rodrigues D.P. \& Back A. 2015. A temporal study of Salmonella enterica serotypes from broiler farms in Brazil. Poult. Sci. 94(3):433-441. <http://dx.doi.org/10.3382/ ps/peu081><PMid:25595481>

WHO 2011. Critically Important Antimicrobials for Human Medicine. 3rd ed. World Health Organization, Geneva, p.1-38.

Yoo A.Y., Yu J.E., Yoo H., Lee T.H., Lee W.H., Oh J.I. \& Kang H.Y. 2013. Role of sigma factor E in regulation of Salmonella Agf expression. Biochem. Biophys. Res. Commun. 430(1):131-136. <http://dx.doi.org/10.1016/j. bbrc.2012.11.025> <PMid:23159630> 